\title{
CROHN'S DISEASE IN KAZAKHSTAN: EPIDEMIOLOGICAL ASPECTS OF INCIDENCE
}

Sauirbay B SAKHANOV ${ }^{1,2}$, https://orcid.org/0000-0002-5496-5313,

Dulat K TUREBAEV ${ }^{1}$, https://orcid.org/0000-0003-1557-3496,

Dariyana M KULMIRZAEVA ${ }^{3,2}$, https://orcid.org/0000-0001-8174-0171,

Saltanat N URAZOVA ${ }^{1}$, https://orcid.org//0000-0002-2331-1261,

Akmaral K AMANSHAYEVA², https://orcid.org/0000-0003-0002-5884,

Zarina A BILYALOVA ${ }^{2}$, https://orcid.org/0000-0002-0066-235x,

Saken K KOZHAKHMETOV ${ }^{1,2}$, https://orcid.org/0000-0002-0075-0376,

Nurbek S IGISSINOV ${ }^{1,2,4,5}$, https://orcid.org/0000-0002-2517-6315

${ }^{1}$ Astana Medical University, Nur-Sultan, Republic of Kazakhstan,

${ }^{2}$ Central Asian Cancer Institute, Nur-Sultan, Republic of Kazakhstan,

${ }^{3}$ National Center of Neurosurgery, Nur-Sultan, Republic of Kazakhstan,

${ }^{4}$ Eurasian Institute for Cancer Research, Bishkek, Kyrgyz Republic,

5International Higher School of Medicine, Bishkek, Republic of Kyrgyzstan

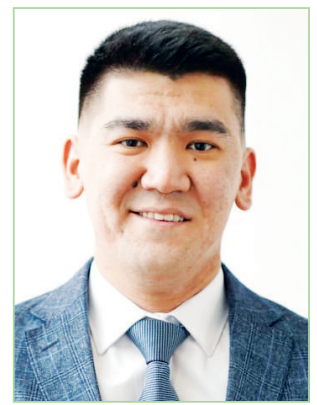

Sakhanov SB

Crohn's disease (CD) is a chronic inflammatory disease of the gastrointestinal tract with an increasing incidence worldwide and widespread in industrialized countries, while the incidence is also increasing in Asia and the Middle East.

Purpose of the study. To study the epidemiological aspects of the incidence of CD in Kazakhstan.

Material and methods. The study for 2013-2018, analyzed the registration and reporting forms of the Ministry of Health of the Republic of Kazakhstan on new cases of CD (ICD: K50) using descriptive and analytical methods of biomedical statistics.

Results. During the study period, 4,671 new cases of CD were registered in Kazakhstan, of which $341(7.9 \%)$ in children under 15 years old, $84(2.0 \%)$ in adolescents (15-17 years old) and adults (18 years old and older) - 4,226 cases (90.9\%). The incidence of CD in Kazakhstan was 4.5 per 100,000 of the total population, while in children $-1.21 \% 000(95 \% \mathrm{Cl}=1.09-1.32)$, in adolescents $-2.12 \%$ o00 $(95 \%$ $\mathrm{Cl}=1.47-2.77)$ and the adult population $-5.86 \%$ oo $(95 \% \mathrm{Cl}=3.20-8.53)$. The trends in the CD incidence as a whole in the entire population had a pronounced tendency to decrease (Tde $=-30.3 \%)$, a slight increase was observed only in the child population (Tin=+1.1\%), and in other studied groups they decreased: in adolescents $-\mathrm{Tde}=-11.9 \%$ and in the adult population $-\mathrm{Tde}=-33.8 \%$.

Conclusion. The study has revealed some aspects of incidence in different age groups and the established trends require further study of this pathology.

Keywords: Crohn's disease, incidence, trends, Kazakhstan.

For reference: Sakhanov SB, Turebaev DK, Kulmirzaeva DM, Urazova SN, Amanshayeva AK, Bilyalova ZA, Kozhakhmetov SK, Igissinov NS. Crohn's disease in Kazakhstan: epidemiological aspects of incidence. Meditsina (Almaty) = Medicine (Almaty). 2020;11-12(221-222): 22-26. DOI: 10.31082/1728452X-2020-221-222 -11-12-22-26

\section{Т¥ жы Р Ы M}

\section{ҚАЗАҚСТАНДАҒЫ КРОН АУРУЫ: АУРУШАҢДЫҚТЫҢ ЭПИДЕМИОЛОГИЯЛЫҚ АСПЕКТІЛЕРІ}

Contacts: Sauirbay B SAKHANOV, 3 year resident of NJSC "Astana Medical University", General Surgery, Member of Public Association "Central Asian Cancer Institute", Nur-Sultan c., e-mail: Sakhanov.s.b@gmail.com

Контакты: Саханов Сәуірбай Бекниязұлы, резидент 3 года обучения курса НАO "Медицинский университет Астана", по специальности общая хирургия, член O० "Central Asian Cancer Institute", г. Нур-Султан, е-mail: Sakhanov.s.b@gmail.com

Received: 24.12 .2020

Сәуірбай Б. САХАНОВ ${ }^{1,2}$, https://orcid.org/0000-0002-5496-5313, Дулат Қ. ТӨРЕБАЕВ 1 , https://orcid.org/0000-0003-1557-3496, Дарияна М. КҮЛМИРЗАЕВА ${ }^{3,2}$, https://orcid.org/0000-0001-8174-0171, Салтанат Н. ОРАЗОВА', https://orcid.org//0000-0002-2331-1261, Ақмарал Қ. АМАНШАЕВА ${ }^{2}$, https://orcid.org/0000-0003-0002-5884, Зарина А. БИЛЯЛОВА ${ }^{2}$, https://orcid.org/0000-0002-0066-235x, Сәкен Қ. ҚОЖАХМЕТОВ ${ }^{1,2}$, https://orcid.org/0000-0002-0075-0376, Нұрбек С. ИГІСІНОВ ${ }^{1,2,4,5}$, https://orcid.org/0000-0002-2517-6315

${ }^{1}$ «Астана медицина университеті» ҚеАҚ, Нұр-Сұлтан қ., Қазақстан Республикасы, ${ }^{2}$ Орталық Азия онкологиялық институты, Нұр-Сұлтан қ., Қазақстан Республикасы, з"Ұлттық нейрохирургия орталығы» АҚ, Нұр-Сұлтан қ., Қазақстан Республикасы, ${ }^{4}$ Еуразиялық онкологиялық зерттеулер институты, Бішкек қ., Қырғызстан Республикасы, ${ }^{5}$ Халықаралық жоғары Медицина мектебі, Бішкек қ., Қырғызстан Республикасы

Крон ауруы (CD) - асқазан-ішек жолдарының созылмалы қабыну ауруы, оның жиілігі бүкіл әлемде артып келеді және өнеркәсіптік дамыған елдерде кең таралған, бұл ауру Азия мен Таяу Шығыста көбеюде.

Reviewer: Bikhanov Nurzhan Aktleutovich, Candidate of Medical Sciences, Senior Resident of the Department of General Surgery, GMPB No. 1 of Akimat of Nur-Sultan city, e-mail: N.bikhanov@mail.ru 
Зерттеу мақсаты. Қазақстандағы КА ауруының эпидемиологиялық аспектілерін зерттеу.

Материал және әдістері. 2013-2018 жылдарға арналған зерттеуде биомедициналық статистиканың сипаттамалық және аналитикалық әдістерін қолдана отырып, КА (XАЖ: K50) жаңа жағдайлары бойынша Қазақстан Республикасы Денсаулық сақтау министрлігінің тіркеу және есеп беру нысандары талданды.

Нәтижелері және талқылауы. Зерттеу кезеңінде Қазақстанда 4671 жаңа КА ауруы тіркелді, оның 341-і (7,9\%) 15 жасқа дейінгі балаларда, 84-і (2,0\%) жасөспірімдерде (15-17 жас) және ересектерде (18 жаста және ересек) - 4226 жағдай (90,9\%). Қазақстанда КА-мен аурушаңдық жалпы халықтың 100000-на шаққанда 4,5 құрады, ал балаларда - 1,21\%оoо (95\% Cl=1,09-1,32), жасөспірімдерде - 2,12\%оо (95\% Cl=1,47-2,77) және ересек тұрғындар - 5.86\%ооо (95\% Cl=3,208,53). Жалпы популяцияда КА-мен ауыру тенденциясы айқын төмендеу тенденциясына ие болды (Ттөм=-30,3\%), сәл өсім тек балалар популяциясында байқалды (Төсу=+1,1\%), ал қалған зерттелген топтарда төмендеді: жасөспірімдерде (Ттөм=-11,9\%) және ересек тұрғындарда Ттөм $=-33,8 \%)$.

Қорытынды. Зерттеу әр түрлі жас топтарындағы аурушаңдықтың кейбір аспектілерін анықтады және қалыптасқан тенденциялар осы патологияны әрі қарай зерттеуді қажет етеді.

Негізгі сөздер: Крон ауруы, аурушаңдығы, тенденциялары, Қазақстан.

\title{
P E 3 Ю M E
}

\section{БОЛЕЗНЬ КРОНА В КАЗАХСТАНЕ: ЭПИДЕМИОЛОГИЧЕСКИЕ АСПЕКТЫ ЗАБОЛЕВАЕМОСТИ}

\begin{abstract}
Саурбай Б. САХАНОВ ${ }^{1,2}$, https://orcid.org/0000-0002-5496-5313, Дулат К. ТОРЕБАЕВ ${ }^{1}$, https://orcid.org/0000-0003-1557-3496, Дарияна М. КҮЛМИРЗАЕВА ${ }^{3,2}$, https://orcid.org/0000-0001-8174-0171, Салтанат Н. ОРАЗОВА', https://orcid.org//0000-0002-2331-1261, Акмарал К. АМАНШАЕВА ${ }^{2}$, https://orcid.org/0000-0003-0002-5884, Зарина А. БИЛЯЛОВА ${ }^{2}$, https://orcid.org/0000-0002-0066-235x, Сакен К. КОЖАХМЕТОВ 1,2 , https://orcid.org/0000-0002-0075-0376, Нурбек С. ИГИСИНОВ ${ }^{1,2,4,5}$, https://orcid.org/0000-0002-2517-6315
\end{abstract}

${ }^{1} \mathrm{H} A O$ «Медицинский университет Астана», г. Нур-Султан, Республика Казахстан, ${ }^{2}$ Central Asian Cancer Institute, е. Нур-Султан, Республика Казахстан,

${ }^{3} \mathrm{AO}$ «Национальный центр нейрохирургии», г. Нур-Султан, Республика Казахстан, ${ }^{4}$ Eurasian Institute for Cancer Research, г. Бишкек, Республика Кырәызстан,

${ }^{5}$ Международная высшая школа медицины, г. Бишкек, Республика Кырәызстан

Болезнь Крона (БК) - хроническое воспалительное заболевание желудочно-кишечного тракта, заболеваемость которым увеличивается во всем мире и имеет широкое распространение в промышленно развитых странах, при этом заболеваемость также растет и в Азии, и на Ближнем Востоке.

Цель исследования. Изучить эпидемиологические аспекты заболеваемости БК в Казахстане.

Материал и методы. Исследование за 2013-2018 гг., проанализированы учетно-отчетные формы МЗ РК о новых случаях БК (МКБ: К50) с использованием дескриптивных и аналитических методов медико-биологической статистики.

Результаты. За изучаемый период в Казахстане был зарегистрирован 4671 новый случай БК, из них у детей до 15 лет - 341 (7,9\%), у подростков (15-17 лет) - 84 (2,0\%) и взрослых (18 лет и старше) - 4226 случаев (90,9\%). Заболеваемость БК в Казахстане составила у 4,5 на 100000 всего населения, при этом у детей - 1,21\%ооо (95\% ДИ=1,09-1,32), у подростков - 2,12\%ооо (95\% ДИ=1,47-2,77) и взрослого населения - 5,86\%оо (95\% ДИ=3,20-8,53). Тренды заболеваемости БК в целом у всего населения имели выраженную тенденцию к снижению $\left(\mathrm{T}_{\mathrm{y}}=-30,3 \%\right)$, незначительный рост был только у детского населения ( $\left.\mathrm{T}_{\text {пр }}=+1,1 \%\right)$, а в остальных изучаемых группах они снижались: у подростков $\left(\mathrm{T}_{\mathrm{y} 6}=-11,9 \%\right)$ и у взрослого населения $\left(\mathrm{T}_{\mathrm{y} 6}=-33,8 \%\right)$

Вывод. Проведенное исследование выявило некоторые аспекты заболеваемости у различных возрастных групп, и установленные тренды требуют дальнейшего изучения данной патологи.

Ключевые слова: болезнь Крона, заболеваемость, тренды, Казахстан.

Для цитирования: Саханов С.Б., Туребаев Д.К., Кульмирзаева Д.М., Уразова С.Н., Аманшаева А.К., Билялова З.А., Кожахметов С.К., Игисинов Н.С. Болезнь Крона в Казахстане: эпидемиологические аспекты заболеваемости. Медицина (Алматы). 2020;11-12(221-222):22-26. DOI: 10.31082/1728-452X-2020-221-222-11-12-22-26 
C rohn's disease $(\mathrm{CD})$ is a chronic inflammatory disease of the gastrointestinal tract, the incidence of which is increasing worldwide. Crohn's disease is more common in industrialized countries, especially North America (20.2 per 100,000 people) and Western Europe (12.7 per 100,000 people), although incidence is increasing in Asia and the Middle East (5.0 per 100,000 people) [1]. The highest annual incidence is observed in Canada (20,2\%oon), Northern Europe (10,6\%ooo), New Zealand (16,5\%о00) and Australia $(29,3 \% 000)$. The prevalence is highest in Europe (322\%ooo), Canada (319\%0oo) and the United States (214\%ooo) [1].

Crohn's disease studies show that causal factors are likely to be the results of interactions between genetic predisposition, environmental factors and altered intestinal microflora, leading to dysregulation of innate and adaptive immune responses $[2,3,4]$.

Crohn's disease affects any part of the gastrointestinal tract. In $50 \%$ of patients, the terminal ileum and colon are affected, $30 \%$ have damage to the small intestine only, and in $20 \%$ of cases, it spreads to the large intestine. In addition, $25 \%$ of patients suffer from perianal complications, including fissures and fistulas. Much less frequently $(<10 \%)$, patients may present with isolated perianal complaints [5].

The purpose of this research is to study the epidemiological aspects of the CD incidence in Kazakhstan.

\section{MATERIALS AND RESEARCH METHODS}

Retrospective study (2013-2018), the source was the materials of registration of new cases of CD (ICD: $\mathrm{K} 50$ ). Analyzed the consolidated reporting form No. 12 of the Ministry of Health of the Republic of Kazakhstan, and used the data of the National Statistics Bureau of the Agency for Strategic Planning and Reforms of the Republic of Kazakhstan on the studied population groups' number [6].

Using the methods of biomedical statistics, extensive, intensive and equalized rates of $\mathrm{CD}$ incidence in children (up to 14 years old), adolescents (15-17 years old), adults (18 and older years) and the entire population of the republic have been calculated. The mean annual values $(\mathrm{P})$, the mean error $(\mathrm{m})$, the $95 \%$ confidence interval $(95 \% \mathrm{CI})$, and the mean annual growth / loss rates (Tde/in, $\%)$ were determined $[7,8]$. The dynamics of incidence was studied for 6 years, while the trends were determined by the least squares method. To calculate the average annual rates of the time series, the geometric mean was used. Estimates of incidence per 100,000 (\%oov) of the relevant population.

The obtained materials were viewed and processed using a computer (Microsoft Office software package (Excel, Word); BIOSTAT and other statistical programs).

\section{RESULTS}

During the study period, 4,671 new cases of CD were registered in Kazakhstan, of which $341(7.9 \%)$ in children under 15 years old, $84(2.0 \%)$ in adolescents (15-17 years old) and adults (18 years old and older) - 4,226 cases $(90.9 \%)$.

The average annual incidence rate of $\mathrm{CD}$ of the entire population of Kazakhstan was $4.5 \pm 1.0 \%$ (950 ( $\%$ CI=2.6-6.4\% \%oo ). The incidence rate of $\mathrm{CD}$ over time tended to decrease from $8.9 \pm 0.2 \%$ \%oo (95\% CI $=8.5-9.3 \%$ \%oo $)$ in 2013 to $2.1 \pm 0.1 \%$ oо ( 95 $\% \mathrm{CI}=2.5-2.9 \%$ ooo $)$ in 2018 , the difference is statistically significant $(t=27.73, p=0.00)$. When leveling out, the above tendency remains, the average annual rate of decline was $\mathrm{Tde}=-30.3 \%$ (Figure 1).

The incidence of CD in Kazakhstan was different in the studied groups. Thus, the average annual $\mathrm{CD}$ incidence rate in children was $1.2 \pm 0.2 \% 000(95 \% \mathrm{CI}=1.1-1.3 \% 000)$, in adolescents $2.1 \pm 0.3 \%$ 0о0 $(95 \% \mathrm{CI}=1.5-2.8 \%$ ooo $)$ and in the adult population $5.9 \pm 1.4 \%$ о0о (95\% $\mathrm{CI}=3.2-8.5 \%$ \%о0) (Figure 2$)$.

Analysis of $95 \% \mathrm{CI}$ of CD incidence rates in the studied population groups showed that they did not overlap, i.e. the differences were statistically significant $(t=2.85, p=0.00$ when comparing children with adolescents, $\mathrm{t}=2.65, \mathrm{p}=0.00$ when comparing adolescents with adults and when comparing children with adults $\mathrm{t}=3.35, \mathrm{p}=0.00$ ).

In dynamics, the incidence of $\mathrm{CD}$ in the child population of the republic decreased from $1.3 \pm 0.1 \%$ oo $(95 \% \mathrm{CI}=0.9-1.6 \%$ oo $)$ in 2013 to $1.1 \pm 0.1 \%$ ooo $(95 \% \mathrm{CI}=0.8-1.4 \%$ ooo $)$ in $2018(\mathrm{t}=0.89$,

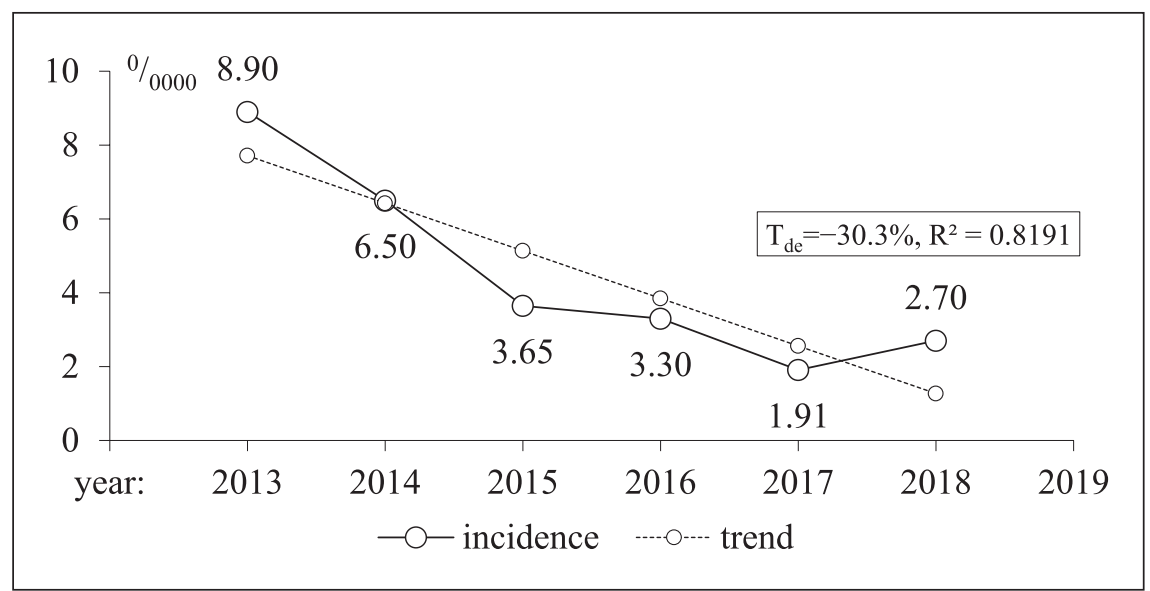

Figure 1 - Dynamics of the total population indicators of CD incidence in Kazakhstan for 2009-2018

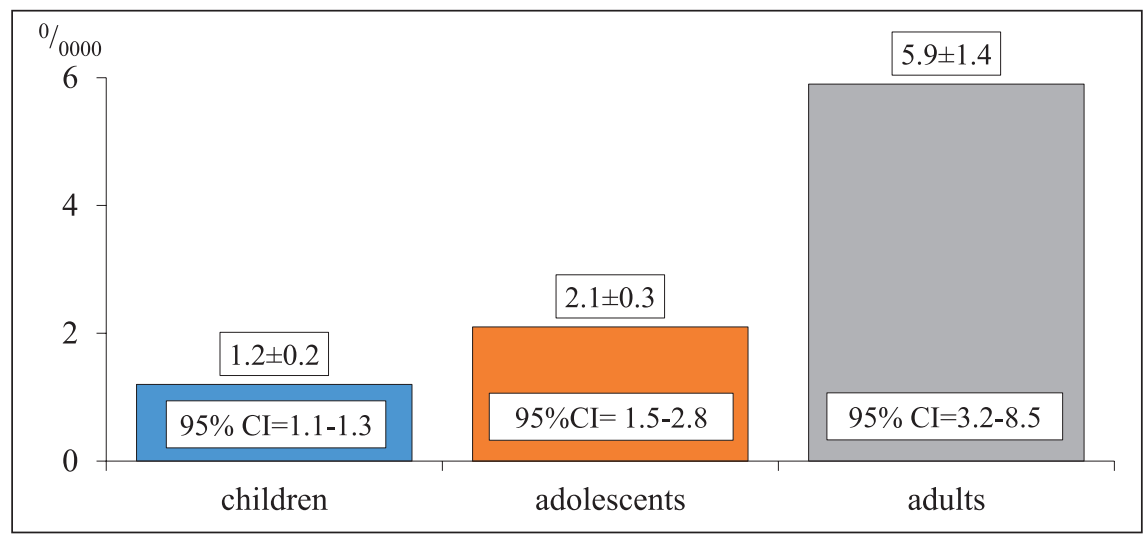

Figure 2 - CD incidence in Kazakhstan for 2013-2018 
$\mathrm{p}=0.37)$, and when leveling off, they tended to an unexpressed increase in $\operatorname{Tin}=+1.1 \%$ (Figure 3 ).

$\mathrm{CD}$ incidence rates in adolescents of the republic decreased from $4.3 \pm 0.8 \%$ ooo $(95 \% \mathrm{CI}=2.8-5.8 \%$ oo $)$ in 2013 to $1.7 \pm 0.5 \%$ (95\% CI $=0.6-2.7 \%$ ooo) in 2018 , the difference was statistically significant $(\mathrm{t}=2.76, \mathrm{p}=0.000)$. The equalized incidence rates repeated this picture, and the average annual rate of decline was Tde $=-11.9 \%$ (Figure 4).

In the adult population of the republic, the incidence indicators of gallstones decreased from $11.9 \pm 0.3 \%$ 000 $(95 \% \mathrm{CI}=11.3$ $12.6 \%$ in 2013 to $3.4 \pm 0.2 \%$ \%oo $(95 \% \mathrm{CI}=3,1-3.7 \%$ \%о0 $)$ in 2018. The difference in the indicated years is statistically significant $(\mathrm{t}=23.57, \mathrm{p}=0.000)$, and the average annual rate of decline during leveling was $\mathrm{Tde}=-33.8 \%$ (Figure 5).

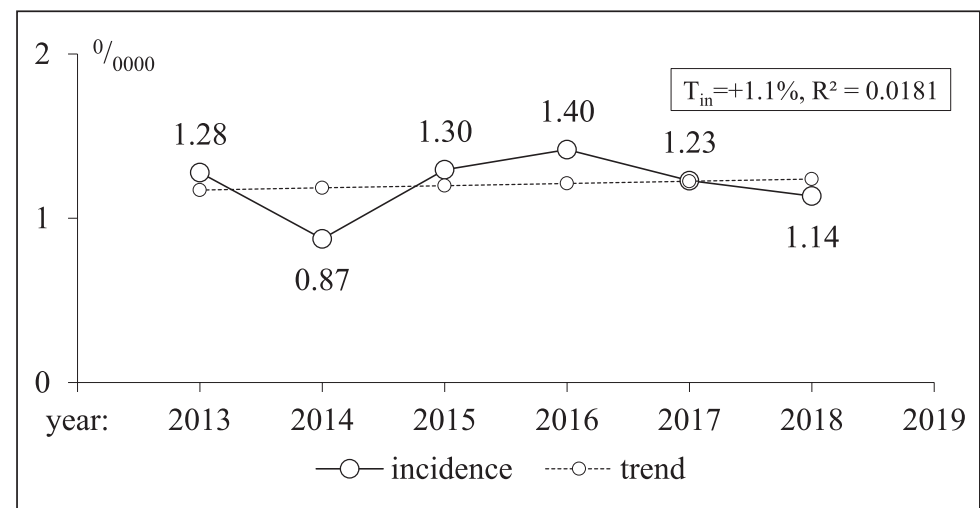

Figure 3 - Dynamics of CD incidence of Child population in Kazakhstan for 2013-2018

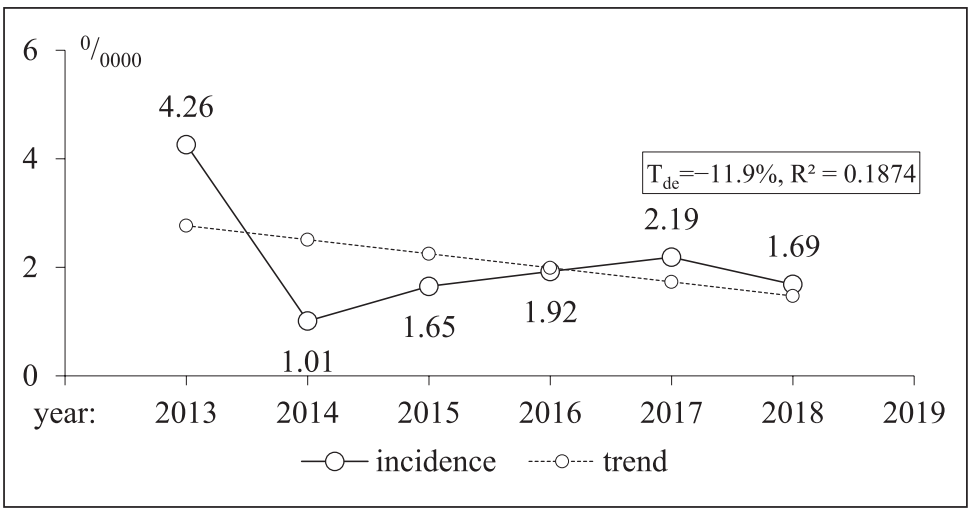

Figure 4 - Dynamics of CD incidence of Adolescent population in Kazakhstan for 2013-2018

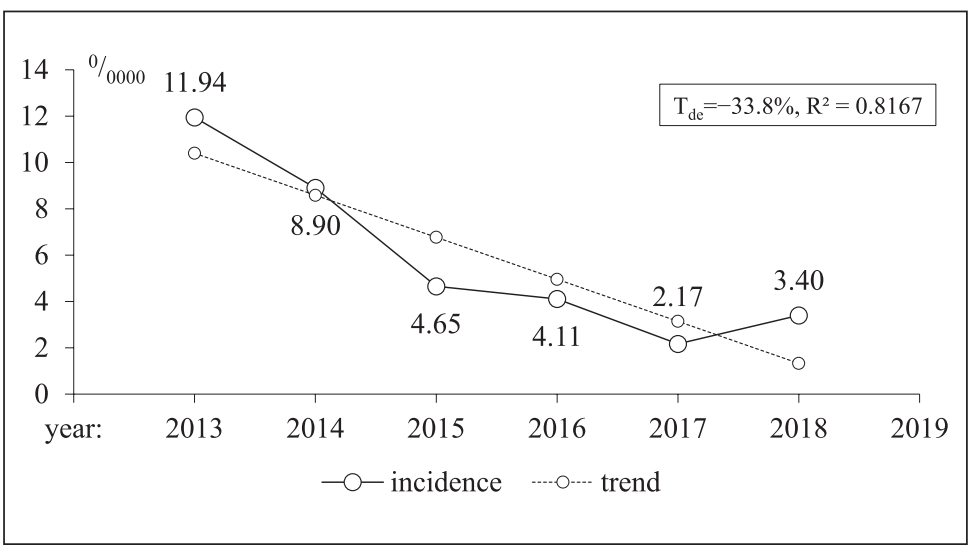

Figure 5 - Dynamics of CD incidence of Adult population in Kazakhstan for 2013-2018

\section{DISCUSSION}

The analysis showed that the number of registered new cases of CD was mainly in the adult population- $90.9 \%$, which is undoubtedly associated with the impact of the environment, which causes genetically predisposed patients [9]. Thus, the incidence rate of $\mathrm{CD}$ with age increases sharply and reaches its maximum values. Trends in the incidence of $C D$ in various studied groups of the population make it possible to assess and characterize the general trend of growth or decline in indicators in different regions of the world [10]. Therefore, in Kazakhstan, the incidence rate for the research years in the studied groups had a pronounced tendency to decrease. A similar picture was observed in Canada between 1996 and 2009 [11]. However, cases may have been underestimated because IBD diagnoses were not made on the basis of clinical diagnoses and medical record reviews, but rather based on a validated database scoring system (i.e. administrative data such as the International Classification of Diseases, codes the ninth review, together with the statement of billing to doctors and, in the case of hospitalization, diagnoses at discharge). A decrease in incidence is also possible due to the issues of accounting and registration of this patients' category, preventive measures and diagnostics carried out $[12,13]$.

Thus, the obtained results can be characterized, on the one hand, as positive (improvement of preventive measures and a decrease in the influence of risk factors), and on the other hand, with vigilance (deterioration of registration and operational underestimation of newly diagnosed patients), not forgetting about the "iceberg" phenomenon (we see only on the water part of the problem). Further indepth, purposeful study of this problem, taking into account the influence of various socio-demographic, medico-geographical, environmental and other factors, will be a priority for our future research.

\section{Research transparency}

Research did not have a sponsorship. The authors are absolutely responsible for presenting the release script for publication.

Declaration about financial and other relations

The authors did not get the honorary for the article. Authors' contribution

Sakhanov Sauirbay - data summary, primary processing of the material, writing the text of the article

Bilyalova Zarina - statistical processing of the material, writing the text of the article (material and methods, conclusion)

Turebaev Dulat, Kulmirzayeva Dariyana, Urazova Saltanat - writing the text of the article (introduction, conclusions)

Amanshayeva Akmaral, Kozhakhmetov Saken writing the text of the article (results), editing

Igissinov Nurbek - concept and design of the study, approval of the final version of the article.

\section{Conflict of interest}

The authors declare no conflict of interest. 


\section{REFERENCES}

1 Molodecky NA, Soon IS, Rabi DM, et al. Increasing incidence and prevalence of the inflammatory bowel diseases with time, based on systematic review. Gastroenterology. 2012;142(1):46-e30. doi: 10.1053/j.gastro.2011.10.001.

2 Torres J, Mehandru S, Colombel JF, Peyrin-Biroulet L. Crohn's disease. Lancet. 2017;389(10080):1741-1755. doi: 10.1016/S01406736(16)31711-1

3 Aniwan S, Park SH, Loftus EV Jr. Epidemiology, Natural History, and Risk Stratification of Crohn's Disease. Gastroenterol Clin North Am. 2017;46(3):463-480. doi: 10.1016/j.gtc.2017.05.003.

4 Ananthakrishnan AN. Epidemiology and risk factors for IBD. Nat Rev Gastroenterol Hepatol. 2015;12(4):205-217. doi: 10.1038/nrgastro.2015.34.

5 Dahlhamer JM, Zammitti EP, Ward BW, Wheaton AG, Croft JB. Prevalence of Inflammatory Bowel Disease Among Adults Aged $\geq 18$ Years - United States, 2015. MMWR Morb Mortal Wkly Rep. 2016;65(42):1166-1169. Published 2016 Oct 28. doi: 10.15585/mmwr. mm6542a3.

6 Ofitsialnyi sait Biuro natsionalnoi statistiki Agentstva po strategicheskomu planirovaniiu i reformam Respubliki Kazakhstan o chislennosti izuchaemykh grupp naseleniia. [The official website of the Bureau of National Statistics of the Agency for Strategic Planning and Reforms of the Republic of Kazakhstan on the size of the studied population groups]. Available from: www.stat.gov.kz

7 Merkov AM, Polyakov LE. Sanitarnaya statistika [Sanitary statistics]. Leningrad, Medicine; 1974:384

8 Glanc S. Mediko-biologicheskaya statistika [Biomedical statistics]. Moscow, Practice; 1999: 460

9 Xavier RJ, Podolsky DK. Unravelling the pathogenesis of inflammatory bowel disease. Nature. 2007;448(7152):427-434. doi: 10.1038/nature06005.

10 Juliao-Baños F, Kock J, Arrubla M, et al. Trends in the epidemiology of inflammatory bowel disease in Colombia by demographics and region using a nationally representative claims database and characterization of inflammatory bowel disease phenotype in a case series of Colombian patients. Medicine (Baltimore). 2021;100(7):e24729. doi: 10.1097/MD.0000000000024729.

11 Leddin D, Tamim H, Levy AR. Decreasing incidence of inflammatory bowel disease in eastern Canada: a population database study. BMC Gastroenterol. 2014;14:140. doi: 10.1186/1471-230X-14-140.

12 Laass MW, Roggenbuck D, Conrad K. Diagnosis and classification of Crohn's disease. Autoimmun Rev. 2014;13(4-5):467-471. doi: 10.1016/j.autrev.2014.01.029

13 Park J, Cheon JH. Incidence and Prevalence of Inflammatory Bowel Disease across Asia. Yonsei Med J. 2021;62(2):99-108. doi:10.3349/ymj.2021.62.2.99

\section{СПИСОК ЛИТЕРАТУРЫ}

1 Molodecky N.A., Soon I.S., Rabi D.M., et al. Increasing incidence and prevalence of the inflammatory bowel diseases with time, based on systematic review // Gastroenterology. 2012;142(1); 46-e30. doi:10.1053/j.gastro.2011.10.001

2 Torres J., Mehandru S., Colombel J.F., Peyrin-Biroulet L. Crohn's disease // Lancet. 2017;38 (10080);1741-1755. doi: 10.1016/ S0140-6736(16)31711-1

3 Aniwan S., Park S.H., Loftus E.V.Jr. Epidemiology, Natural History, and Risk Stratification of Crohn's Disease // Gastroenterol Clin North Am. 2017;46(3): 463-480. doi: 10.1016/j.gtc.2017.05.003.

4 Ananthakrishnan A.N. Epidemiology and risk factors for IBD // Nat Rev Gastroenterol Hepatol. 2015;12 (4);205-217. doi:10.1038/ nrgastro. 2015.34

5 Dahlhamer J.M., Zammitti E.P., Ward B.W., Wheaton A.G., Croft J.B. Prevalence of Inflammatory Bowel Disease Among Adults Aged $\geq 18$ Years - United States, 2015 // MMWR Morb Mortal Wkly Rep. 2016;65(42):1166-1169. Published 2016 Oct 28. doi: 10.15585/ mmwr.mm6542a3

6 Официальный сайт Бюро национальной статистики Агентства по стратегическому планированию и реформам Республики Казахстан о численности изучаемых групп населения. www.stat.gov.kz

7 Мерков А.М., Поляков Л.Е. Санитарная статистика. - Л., 1974. $-384 \mathrm{c}$

8 Стентон Гланц. Медико-биологическая статистика. - М.; 1999. $-460 \mathrm{c}$.

9 Xavier RJ, Podolsky DK. Unravelling the pathogenesis of inflammatory bowel disease // Nature. 2007;448 (7152); 427-434. doi: 10.1038/nature06005

10 Juliao-Baños F., Kock J., Arrubla M., et al. Trends in the epidemiology of inflammatory bowel disease in Colombia by demographics and region using a nationally representative claims database and characterization of inflammatory bowel disease phenotype in a case series of Colombian patients // Medicine (Baltimore). 2021;100 (7): e24729. doi: 10.1097/MD.0000000000024729

11 Leddin D., Tamim H., Levy A.R. Decreasing incidence of inflammatory bowel disease in eastern Canada: a population database study // BMC Gastroenterol. 2014;14;140. doi: 10.1186/1471-230X-14-140

12 Laass M.W., Roggenbuck D., Conrad K. Diagnosis and classification of Crohn's disease. // Autoimmun Rev. 2014;13(4-5);467-471. doi: 10.1016/j.autrev.2014.01.029

13 Park J., Cheon J.H. Incidence and Prevalence of Inflammatory Bowel Disease across Asia. // Yonsei Med J. 2021;62(2);99-108. doi: 10.3349/ymj.2021.62.2.99 